\title{
A new member of the genus Antarctonemertes (Hoplonemertea, Nemertea) from Antarctic waters
}

\author{
Sergi Taboada ${ }^{1}\left[\right.$ Carlos Leiva $^{2} \cdot$ Juan Junoy $^{3} \cdot$ Frances Alexander $^{4,5} \cdot$ Ana Riesgo $^{1}$
}

Received: 1 September 2017 / Revised: 27 February 2018 / Accepted: 28 February 2018 / Published online: 9 March 2018

(c) The Author(s) 2018. This article is an open access publication

\begin{abstract}
The phylum Nemertea is an important component of the benthic ecosystems of the Southern Ocean, but its biodiversity is still relatively poorly known in Antarctic waters. There are few common and well-known nemertean species occurring in the shallow Antarctic waters, and these include the congeneric Antarctonemertes valida (Bürger, 1893) and Antarctonemertes riesgoae Taboada et al., 2013, two relatively small brooding hoplonemerteans whose females lay eggs inside cocoons. A third Antarctic member of the genus, Antarctonemertes belgica (Bürger, 1904), was reported only in the original description. Here we document the existence of a fourth Antarctic member of the genus Antarctonemertes originally described as Tetrastemma unilineatum Joubin, 1910. Our phylogenetic analysis resulted into the placement of the new Antarctonemertes in a robustly supported clade-Antarctic Antarctonemertes-containing the other two congeneric Antarctic species (A. valida and $A$. riesgoae), and pairwise $C O I$ molecular distances between the three species ranged from 5.2 to $6.2 \%$ ( $p$ distance). The analysis of 104 COI sequences of the three species showed star-like haplotype networks, as in other studies on Antarctic invertebrates. Antarctonemertes unilineata comb. nov. is similar in shape to its Antarctic congeneric relatives and its most prominent morphological character is a dorsal mid-longitudinal band present along the body. We also document the presence of a cocoon built by females of $A$. unilineata comb. nov., a character shared with its Antarctic congeners analysed here. Although the four Antarctic Antarctonemertes species appear to overlap their distribution, A. riesgoae, A. valida and A. belgica appear in sympatry in the West Antarctic shores while A. unilineata comb. nov. has been mainly found in the East Antarctic shores and sub-Antarctic Islands.
\end{abstract}

Keywords Barcode gap $\cdot$ Casey Station $\cdot$ Deception Island $\cdot$ Haplotype network $\cdot$ Phylogeny $\cdot$ Taxonomy

\section{Introduction}

Electronic supplementary material The online version of this article (https://doi.org/10.1007/s00300-018-2298-1) contains supplementary material, which is available to authorised users.

Sergi Taboada

sergiotab@gmail.com

1 Life Sciences Department, The Natural History Museum, Cromwell Road, London SW7 5BD, UK

2 Departament de Biologia Evolutiva, Ecologia i Ciències Ambientals, Facultat de Biologia, Universitat de Barcelona, Avda. Diagonal 645, 08028 Barcelona, Spain

3 Departamento de Ciencias de la Vida, AP 20 Campus Universitario, Universidad de Alcalá, 28805 Alcalá de Henares, Spain

4 Marine Ecology Research Centre, Southern Cross University, Lismore, NSW 2480, Australia

5 Australian Antarctic Division, Kingston, TAS 7050, Australia
Nemerteans, commonly known as ribbon worms, are a group of marine invertebrates whose taxonomy has commonly been based on a combination of detailed descriptions of external and internal features (e.g. Sundberg et al. 2009; Taboada et al. 2013), the latter traditionally considered as the diagnostic characters to differentiate among taxa (Sundberg et al. 2016a). However, most of the described nemertean species are known to have inadequate taxonomic descriptions, either lacking or having inadequately documented histological characters and/or lacking proper descriptions of their external features that are commonly lost as a preservation artefact (Gibson 1995). To solve this taxonomical conundrum, a group of nemertean taxonomic experts have recently proposed that traditional histological techniques to describe internal characters are not essential for identification and description purposes (Sundberg et al. 2016a). 
Sundberg et al. (2016a), as opposed to other authors (e.g. Gibson 1985; Roe et al. 2007), proposed that histological features should not be included as a prerequisite to describe/ redescribe new nemertean fauna and that they instead should only be used to address questions about internal organ systems functionality and evolution. To support this statement, Strand et al. (2013) suggested that there is no strong evidence that nemertean identifications are more accurate when based on internal features, rather than in external. In fact, several internal characters used to differentiate between species and genera of nemerteans can sometimes show high levels of intraspecific variation (Envall and Sundberg 1993). In their manifesto, Sundberg et al. (2016a) suggested that description and redescription of nemertean species should be accepted if they contain information about DNA sequences (at least cytochrome $c$ oxidase-COI-), a description of the external characters including information on the ecology of the species, and type material of voucher specimens being fixed in preservatives ensuring future studies on the DNA of the species.

Despite the relatively low number of described nemertean species in the Southern Ocean (Kajihara et al. 2008), this group of organisms plays an important role in these waters, with its overall biodiversity being clearly underestimated, at least for the western Antarctic Peninsula (Mahon et al. 2010). A few well-known nemertean species commonly occur in the shallow Antarctic waters. One of the most conspicuous examples is Parborlasia corrugatus (McIntosh, 1876), a frequent and relatively large heteronemertean with a circumpolar distribution, also reported from sub-Antarctic Islands (Thornhill et al. 2008). Other examples include the congeneric Antarctonemertes valida (Bürger, 1893) and Antarctonemertes riesgoae Taboada et al., 2013, two relatively small brooding hoplonemerteans whose females lay eggs inside cocoons, which commonly occur in the intertidal and shallow subtidal Southern Ocean (Taboada et al. 2013). The two Antarctonemertes and P. corrugatus should be considered as exceptional cases in the Southern Ocean in the sense that they have been extensively characterised either under morphological (including both external and internal features) or genetic approaches (Gibson 1983; Thollesson and Norenburg 2003; Thornhill et al. 2008; Taboada et al. 2013).

Here we document the existence of the fourth Antarctic member of the genus Antarctonemertes, which was originally described as Tetrastemma unilineatum Joubin, 1910 and redescribed by Gibson and Tait (1984) using traditional histological methods. Following specifications by Sundberg et al. (2016a), we describe the external morphological characters of the species (including details on the cocoon built by females) and combine this information with phylogenetic data using a nuclear and two mitochondrial markers. Furthermore, we provide molecular distances related to $A$. riesgoae and $A$. valida using a fragment of the cytochrome $c$ oxidase I $-\mathrm{COI}-$ gene and give additional details regarding the haplotype network patterns of the three Antarctonemertes species.

\section{Materials and methods}

\section{Sample collection and preservation}

Specimens of $A$. valida $(N=26)$ and A. riesgoae $(N=24)$ used in this study were collected, during January 2013 by hand at low tide from Deception Island (South Shetland Islands) (Fig. 1A). A population of T. unilineatum $(N=42)$ was collected during the 2013/2014 austral summer season at Beall Island near Casey station, East Antarctica (Fig. 1B), a location almost $5000 \mathrm{~km}$ apart from Deception Island. All specimens were collected from the underside of rocks and algae, and after collection the specimens were sorted in the lab, photographed alive, preserved in absolute ethanol and immediately stored at $-20{ }^{\circ} \mathrm{C}$ until DNA extraction.

\section{DNA extraction and amplification}

Genomic DNA was extracted from each of the individuals (a portion of the midbody) using the Tissue and Blood Qiagen extraction kit (Qiagen, www.qiagen.com) and the Speedtools Tissue DNA Extraction kit (Biotools, www.biotools.eu) following the protocol provided by the manufacturer. Specific primers (ANT_COI-F/ANT_COI-R) and amplification protocols shown in Online Resource 1 were used to amplify a fragment of ca. $600 \mathrm{bp}$ of $\mathrm{COI}$ for the total 92 individuals of the three Antarctonemertes species. In addition, ca. $400 \mathrm{bp}$ of $16 \mathrm{~S}$ rDNA ( $16 \mathrm{~S}$ ) and ca. $900 \mathrm{bp}$ of $28 \mathrm{~S}$ rDNA (28S) were amplified for two individuals of T. unilineatum using the primers and protocols specified in Online Resource 1. Each PCR reaction mix for the primers $16 S$ and $28 S$ contained $10 \mu \mathrm{L}$ of REDTaq ReadyMix ${ }^{\mathrm{TM}}$ (Sigma-Aldrich), $6.4 \mu \mathrm{L}$ of water, $0.8 \mu \mathrm{L}$ of each primer and $2 \mu \mathrm{L}$ of DNA extraction of each individual. For the primers ANT_COI-F/ANT_COI-R each PCR reaction mix contained $17.75 \mu \mathrm{L}$ of water, $0.5 \mu \mathrm{L}$ of $100 \mathrm{nM}$ dNTPs (Thermo Fisher Scientific), $1 \mu \mathrm{L}$ of each primer, $0.5 \mu \mathrm{L}$ of DNA extraction of each individual, and the following reagents from the BIOTAQ ${ }^{\mathrm{TM}}$ DNA Polymerase Kit (Bioline): $2.5 \mu \mathrm{L}$ of $10 \times$ NH4 Reaction Buffer, $1.25 \mu \mathrm{L}$ of $\mathrm{MgCl}_{2}$ Solution and $0.5 \mu \mathrm{L}$ of BIOTAQ DNA Polymerase. Sequencing was conducted on an ABI 3730XL DNA Analyser (Applied Biosystems) at the Molecular Core Labs (Sequencing Facility) of the Natural History Museum of London using the primers mentioned above. 


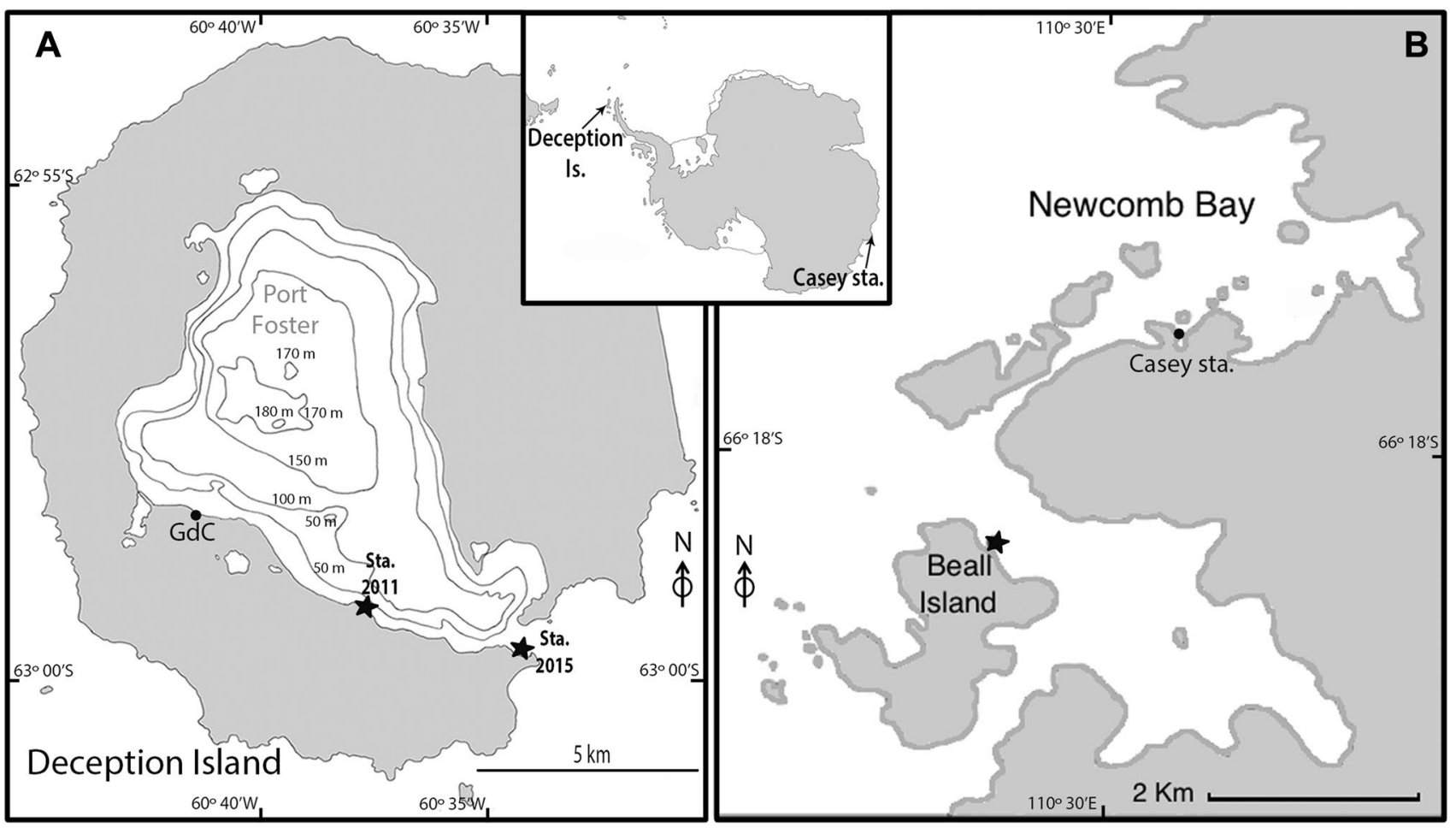

Fig. 1 Map of the study areas. Insert, map of Antarctica indicating the approximate location of Deception Island (South Shetland Islands) and Casey Antarctic Station. a Deception Island, where samples of Antarctonemertes riesgoae and Antarctonemertes valida were collected. Sta. 2015, indicates the location where samples studied

\section{Morphological analysis}

During the course of the morphological examinations, we suspected that the individuals identified as Tetrastemma unilineatum in fact belonged to the genus Antarctonemertes (see details in Results). Therefore, the formal morphological description of Antarctonemertes unilineata comb. nov. was based primarily on external characters observed in live and preserved specimens in absolute ethanol. Additionally, we included information based on histological sections of three A. unilineata comb. nov. individuals collected at the Gerlache Strait and Paradise Bay (de la Uz 2005).

\section{Phylogenetic analysis}

Molecular analyses to place the new A. unilineata comb. nov. within its phylogenetic context were conducted with datasets for $C O I, 16 S$ and $28 S$ using sequences available in NCBI and sequences obtained in this study (Online Resource 2). In total, 36 terminal taxa were used in the analysis including a selection of hoplonemerteans in order to capture the overall diversity of the group and Nipponnemertes sp., Nipponnemertes pulchra (Johnston, 1837) and Nectonemertes mirabilis Verrill, 1892 as outgroups for tree rooting as in a here were collected; Sta. 2011, indicates the location where samples studied in Taboada et al. (2013) were collected. b Casey station area showing the location at Beall Island where samples of Antarctonemertes unilineata comb. nov. were collected

previous study (Taboada et al. 2013). Overlapping sequence fragments were assembled into consensus sequences using the software Geneious vs. 8.1.7 (http://www.geneious.com, Kearse et al. 2012), and aligned using Q-INS-I option of MAFFT (Katoh et al. 2002). The most appropriate evolutionary model for each gene $(\mathrm{GTR}+\mathrm{I}+\mathrm{G}$ for $\mathrm{COI}$ and $28 \mathrm{~S}$ and GTR+G for $16 S$ ) was obtained by running the alignments in jModelTest (Posada 2008) via the Akaike Information Criterion (AIC). Sequences of the three genes were then concatenated and analyses were conducted after removing uncertain alignment positions of the $16 \mathrm{~S}$ and $28 \mathrm{~S}$ sequences using Gblocks (Castresana 2000). Gblocks were run using the following settings: minimum number of sequences for a flank position $=17$; maximum number of contiguous nonconserved positions $=10$; minimum length of a block $=5$; allowed gap positions $=$ with half.

A combined analysis using the three concatenated genes (with $16 \mathrm{~S}$ and $28 S$ Gblocked) was conducted using Maximum Likelihood analyses (ML) with RAxML (Stamatakis 2006; Stamatakis et al. 2008) and Bayesian inference analyses (BI) with MrBayes 3.1.2 (Ronquist and Huelsenbeck 2003). ML were run using 10 heuristic searches (SPR and NNI) and robustness of the nodes was determined with 10 runs and 500 replicates using the evolutionary model 
mentioned above; concatenated sequences were partitioned by gene and the protein coding gene (COI) was partitioned into codon positions. BI analyses were run twice for each dataset with four chains for 15 million generations $(25 \%$ trees discarded as burn-in) sampling a tree every 1000 generations; partition codons were used for $C O I$ and the best evolutionary models previously inferred for every gene were applied. Convergence among chains, mixing within chains (i.e. ESS values) and the number of burn-in generations were monitored with the programme TRACER 1.6 (Rambaut et al. 2014). Results were visualised in FigTree v.1.4.2 (Rambaut 2006).

\section{Haplotype networks and genetic distances}

The COI sequences of $A$. riesgoae and A. valida generated in our study were combined with $C O I$ sequences available in GenBank for A. valida (KC754990-KC754994 and KF935537) and for A. riesgoae (KC754995-KC754999 and KF935538; Online Resource 3). COI sequences of A. riesgoae $(N=30)$, A. valida $(N=32)$ and A. unilineata comb. nov. $(N=42)$ were aligned in Geneious vs. 8.1.7 using Q-INS-I option in MAFFT. The final 5' and 3' ends of the alignment were trimmed to obtain sequences of equal size for all individuals and this alignment was used to construct an unrooted haplotype network with the programme PopART (http://popart.otago.ac.nz) under the Median Joining network option (Bandelt et al. 1999). Polymorphic sites and levels of DNA polymorphism were calculated for each lineage on each substrate using DnaSP versus 5.10.1 (Librado and Rozas 2009), and included number of haplotypes $(H)$, haplotype diversity $(H d)$ and nucleotide diversity $(\pi)$.

Minimum genetic distances based on uncorrected $p$ distance and Kimura 2-parameter (K2p) models were calculated using MEGA vs. 5.2.2 (Tamura et al. 2011); the default parameters were used to calculate distances between and within the three species. In addition, the same distances were calculated between and within monophyletic genera and a selection of the paraphyletic genera (Oerstedia and Prosorhochmus) based on the phylogenetic results.

\section{Results}

\section{Systematics}

Genus Antarctonemertes Friedrich 1955.

Antarctonemertes unilineata comb. nov. (Figure 2A-D).

Tetrastemma unilineatum Joubin 1910; Wheeler, 1940; Coe, 1950; Dawson, 1957, 1969, 1971; Gibson and Tait 1984 Prostoma unilineatum Baylis 1915.

Material examined 51 individuals collected from Beall Island $\left(66^{\circ} 30.426^{\prime} \mathrm{S}, 110^{\circ} 45.851^{\prime} \mathrm{E}\right)$ near Casey station
(Fig. 1B; Casey Sta.); Leg. F. Alexander, 3 January and 13 February 2014. Collected at low tide from an intertidal rocky area at depths ca. $1 \mathrm{~m}$, found on the underside of rocks and associated with the macroalgae Palmaria decipiens (Reinsch) R.W.Ricker, 1987. Specimens were transferred to aquaria at the Antarctic Australian Division Marine Research Facility. Live specimens were kept at $0 \pm 1{ }^{\circ} \mathrm{C}$ and fed frozen prawn, fish and phytoplankton and preserved in absolute ethanol on 19 October and 6 December 2015. All specimens are deposited at the Natural History Museum of London (NHMUK2018-76 to NHMUK2018-126; Online Resource 4).

External features Preserved specimens 10-22 mm long, up to $2.5 \mathrm{~mm}$ wide. Body tapering at anterior and posterior ends, dorsally rounded, ventrally flattened. Live specimens with triangular head having a prominent median lobe resembling the lancet-shaped type represented by Sundberg et al. (2009); head shape pointed in living disturbed organisms (Fig. 2A) and rounded after preservation. One pair of cephalic furrows evident ventrally, forming a semicircular arch. In life, dorsal colour light brown with a prominent darker mid-longitudinal band from the anterior to the posterior end; ventral surface dirty white or pale yellow; V-shaped cephalic white band with the apex pointing backwards (Fig. 2A). After preservation body colour and longitudinal and head bands retained (Fig. 2B).

Proboscis apparatus resembles that of most other monostiliferan hoplonemerteans with two accessory stylet pouches with 3-5 accessory stylets each, with a length of $120-130 \mu \mathrm{m}$ after measuring two individuals of 6.0 and $5.5 \mathrm{~mm}$ long, respectively (Fig. 2D).

Cocoons Transparent and elongated, $15 \mathrm{~mm}$ long by $4 \mathrm{~mm}$ maximum width, dorsally rounded, firmly attached to rocks and algae by its ventrally flattened section. Cocoons have two openings. From 50 to 125 eggs per cocoon, each egg about $0.5 \mathrm{~mm}$ in diameter, dark pink in life becoming white opaque after preservation (Fig. 2C).

Habitat Specimens of A. unilineata comb. nov. were collected in the shallow Antarctic waters of Beall Island, $\left(66^{\circ} 30.426^{\prime} \mathrm{S}, 110^{\circ} 45.851^{\prime} \mathrm{E}\right)$ near Casey station, East Antarctica (Fig. 1B). Adult individuals were found attached to intertidal rocks and macroalgae. The species has also been recorded in other localities from the East Antarctica including Cape Adare (Joubin 1910; Baylis 1915), the entrance to McMurdo Sound (Baylis 1915), Cape Denison (Wheeler 1940) and offshore from Casey station (Gibson and Tait 1984), as well as from the sub-Antarctic Crozet and Kerguelen Islands (Wheeler 1940). Antarctonemertes unilineata comb. nov occurs from the intertidal zone up to $379 \mathrm{~m}$ on muddy sediment and on shingle (Joubin 1910; Baylis 1915; Wheeler 1940; Gibson and Tait 1984). More recently, A. unilineata comb. nov has also been reported from the Gerlache 

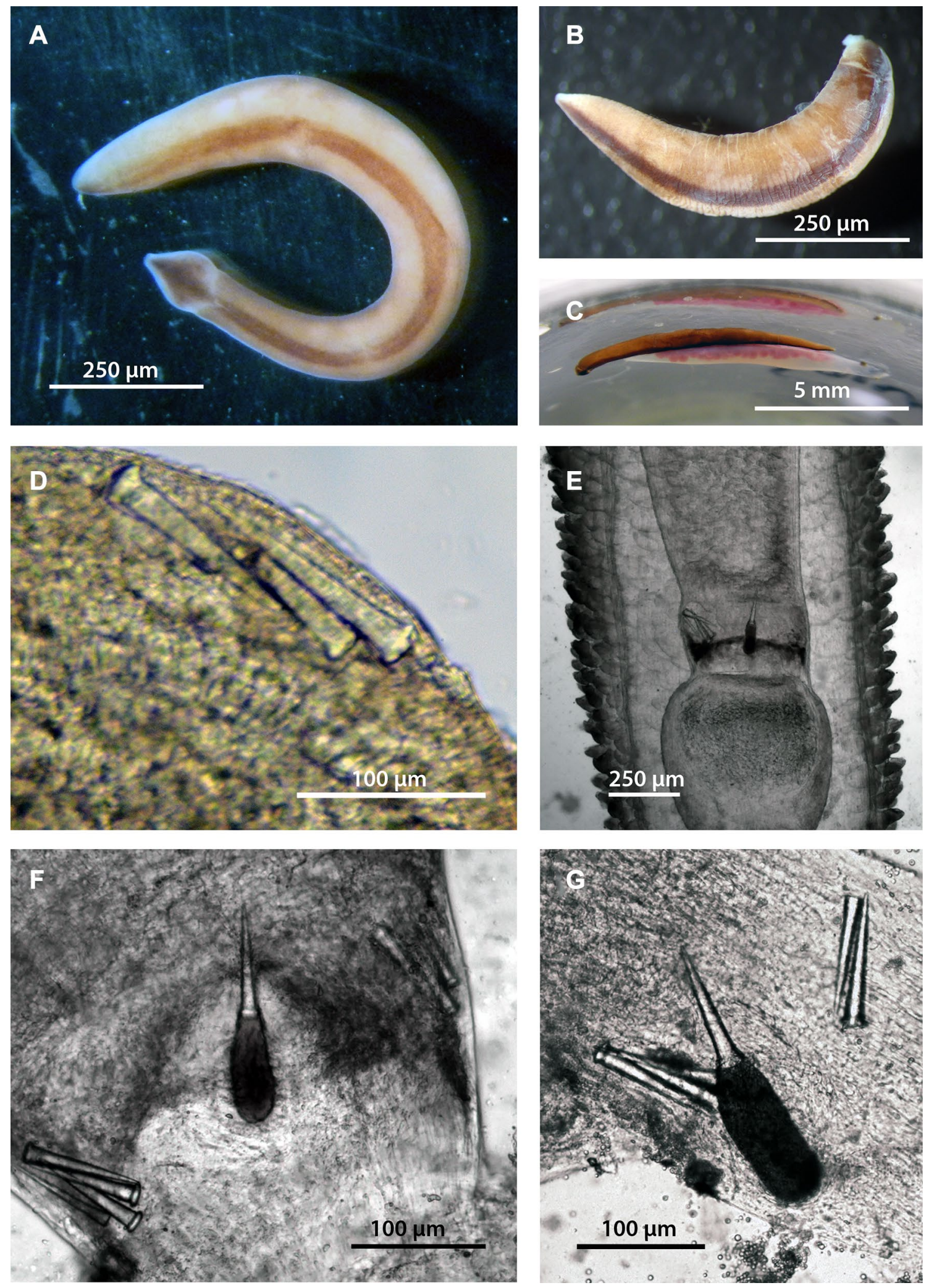

Fig. 2 Live specimens of Antarctonemertes unilineata comb. nov. and detail of stylets of the three Antarctonemertes species. a Live specimen of Antarctonemertes unilineata comb. nov. b Preserved specimen of A. unilineata comb. nov. c Live female of A. unilineata comb. nov. inside a cocoon brooding its eggs. d Accessory stylets in a pre- served specimen of A. unilineata comb. nov. e Anterior part of a live specimen of Antarctonemertes riesgoae indicating the stylets (arrow) f Detail of the stylets of $A$. riesgoae in a live specimen. $\mathbf{g}$ Detail of the stylets of Antarctonemertes valida in a live specimen 
Strait and Paradise Bay at 46 and $10 \mathrm{~m}$ depth, respectively (de la Uz 2005).

Remarks The genus Antarctonemertes was established by Friedrich (1955) for two Southern Ocean nemerteans previously assigned to the genus Tetrastemma, namely Antarctonemertes valida and Antarctonemertes belgica (Bürger, 1904). As noted by Chernyshev (1999), Antarctonemertes is similar to nemerteans of the genus Tetrastemma, distinguished by the presence of lateral nerve cords with a small accessory nerve, and by separation of the dorsal vessel from the rhynchocel wall. The redescription of Tetrastemma unilineatum by Gibson and Tait (1984) did not report the presence of this small accessory nerve, although specimens collected from the Gerlache Strait and Paradise Bay appeared to have a small accessory nerve in the lateral nerve cords (de la Uz 2005), as it has already been described for its congeneric Antarctonemertes valida and Antarctonemertes riesgoae (Taboada et al. 2013). Our phylogenetic analyses indicate that A. valida, A. riesgoae and A. unilineata comb. nov. form a monophyletic clade (see Phylogenetic analysis), giving support to our suggestion to transfer $T$. unilineatum to the genus Antarctonemertes. Previous descriptions of A. unilineata comb. nov never mentioned the presence of a cocoon built by females for egg protection, but instead reported unusually large egg sizes ranging from 0.2 to $0.4 \mathrm{~mm}$ in diameter (Baylis 1915; Wheeler 1940), similar to those reported in A. riesgoae and A. valida (Taboada et al. 2013). Our observations confirm that $A$. unilineata comb. nov is the fourth brooding nemertean occurring in Antarctic waters after Amphiporus incubator Joubin, 1914, Antarctonemertes valida, and A. riesgoae (Joubin 1914; Taboada et al. 2013). Similar to A. valida and A. riesgoae, females of $A$. unilineata comb. nov also built a transparent cocoon with openings at each end. Although in the original description of A. belgica the presence of eggs was described, a cocoon was never reported in this species (Bürger 1904). Colour of the eggs in life differs in the three Antarctonemertes species for which we have information: in A. valida they appear to be white, yellowish, orange or pink (occasionally violet), in A. riesgoae they are blue to light purple, while in A. unilineata comb. nov they are dark pink (Fig. 2C). As for the external appearance of adults, Amphiporus incubator, Antarctonemertes valida and A. riesgoae all appear to have a similar dorsal colour in life (brown to dark brown), while A. unilineata comb. nov has a light brown dorsum (Fig. 2A-B); A. belgica was originally reported as milky white turning to brown-greyish after preservation (Bürger 1904). Both A. unilineata comb. nov and A. riesgoae have a $\mathrm{V}$-shaped cephalic band directed backwards but the former also has a distinctive dorsal mid-longitudinal band (darker than the rest of the body dorsum) that extends along the body of the animal (Fig. 2A-B); A. valida has two white lateral patches while $A$. incubator has no particular cephalic pattern (Joubin 1914; Taboada et al. 2013). No particular cephalic pattern was described for A. belgica (Bürger 1904). Similar to A. incubator and A. riesgoae, A. unilineata comb. nov has a pair of cephalic furrows evident ventrally forming a semicircular arch, while A. valida has two pairs of cephalic furrows forming a ventral, anterior directed ' $\mathrm{V}$ '. Antarctonemertes unilineata comb. nov and A. valida have 10 proboscideal nerves, while $A$. riesgoae has 12 proboscideal nerves (Gibson and Tait 1984; de la Uz 2005; Taboada et al. 2013). Antarctonemertes riesgoae, A. valida and A. unilineata comb. nov appear to have a similar stylet apparatus, with two accessory stylet pouches and smooth stylets (Fig. 2D-G); cylindrical basis of stylets could only be observed in A. valida and A. riesgoae (Fig. 2E-G). No observations of these features were reported for A. belgica (Bürger 1904). Although a comprehensive information about the distribution of the different species in Antarctic waters is lacking, A. incubator, A. belgica, A. valida and A. riesgoae are sympatric species that have been recorded only in the West Antarctica (Bürger 1904; Joubin 1914; Taboada et al. 2013), while A. unilineata comb. nov appears to be more common in East Antarctica and the sub-Antarctic Kerguelen and Crozet Islands, occasionally occurring in sympatry with $A$. valida and A. riesgoae in the Antarctic Peninsula (de la Uz 2005; authors' personal observations).

\section{Phylogenetic analysis}

The consensus tree obtained from the Bayesian Inference (BI) analysis of the concatenated alignment is shown in Fig. 3, which also summarises the support recovered from the Maximum Likelihood (ML) analysis. The concatenated alignment consisted of 1842 bp (539 bp of COI, $374 \mathrm{bp}$ of $16 S$ and 929 bp of $28 S$ ), and both BI and ML analyses recovered similar tree topologies. Antarctonemertes unilineata comb. nov. appeared in a robustly supported clade -Antarctic Antarctonemertes- as sister to the other two congeneric Antarctic species (A. valida and A. riesgoae) (Fig. 3). Although recovered with a low support in the BI analysis, the Antarctic Antarctonemertes clade was sister to a clade including several species from different genera including the congeneric Antarctonemertes varvarae Chernyshev, 1999 and Antarctonemertes phyllospadicola (Stricker, 1985), originally described from the coast of Russia and the Pacific coast of the USA, respectively (Stricker 1985; Chernyshev 1999).

\section{Haplotype networks and genetic distances}

A $505 \mathrm{bp}$ fragment of $C O I$ was analysed for a total of 104 organisms including 30 individuals of $A$. riesgoae, 32 of A. valida and 42 of $A$. unilineata comb. nov. The haplotypes for the three species were independent and were connected by 24 mutational steps between $A$. unilineata comb. nov. and A. valida and also between A. valida and A. riesgoae 


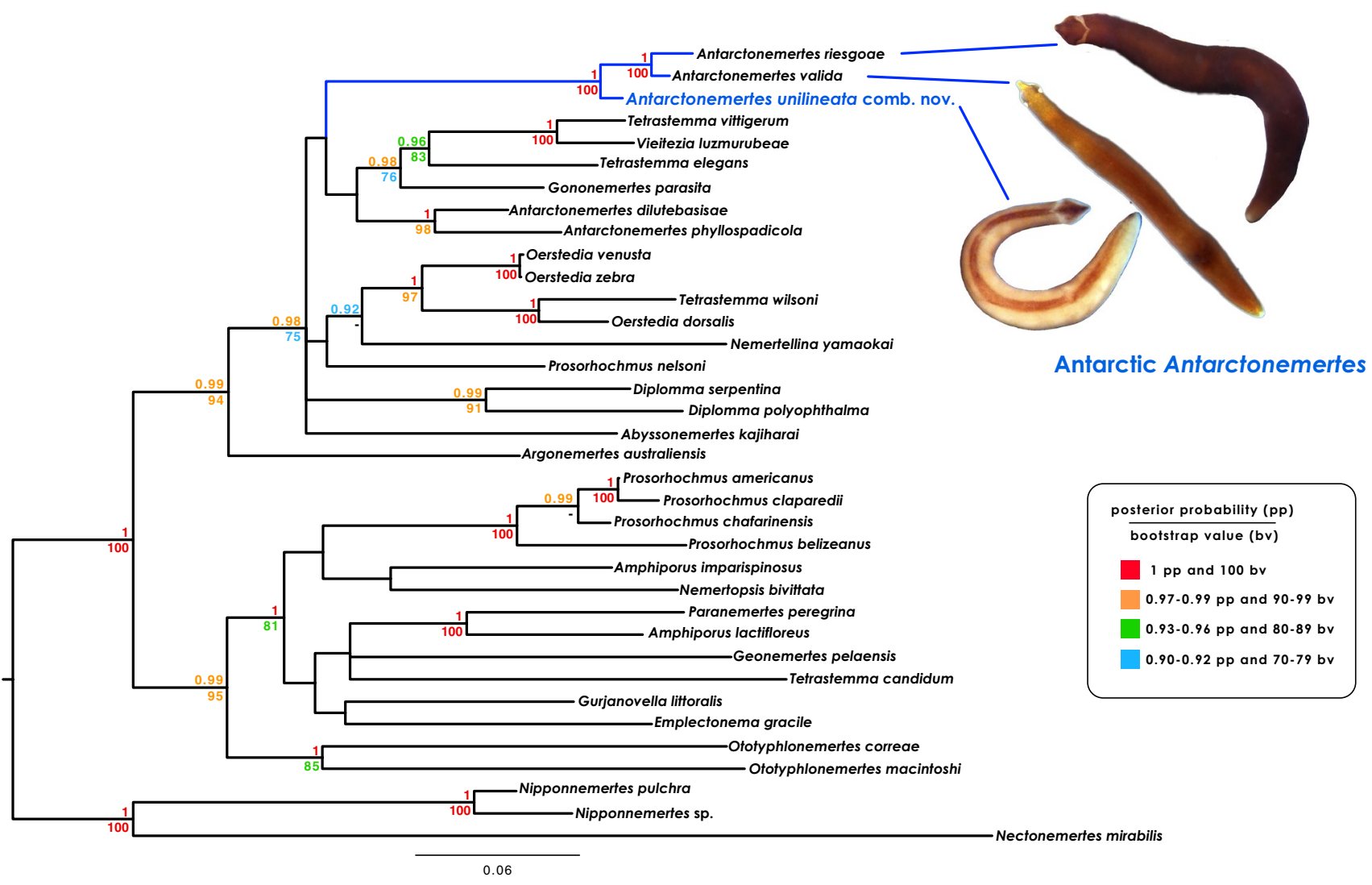

Fig. 3 Phylogenetic tree of selected hoplonemerteans based on the concatenated analyses of $\mathrm{COI}, 16 \mathrm{~S}$ and $28 \mathrm{~S}$ from Bayesian inference analysis (BI). Posterior probability -pp- (above) and bootstrap -bs- values (below) are indicated on each node. Dash on the node indicates node not supported by Maximum Likelihood (ML) analysis. Red colour indicates $\mathrm{pp}=1$ and $\mathrm{bv}=100$; orange colour indicates

(Fig. 4). Haplotype and nucleotide diversity were low for A. riesgoae ( $H d=0.253$ and $\pi=0.0005)$ and $A$. valida ( $H d=0.236$ and $\pi=0.0005$ ) accounting for five and four haplotypes, respectively (Table 1). Both species displayed star-like haplotype networks with a dominant haplotype (Hrie_1 $=87 \%$; Hval_1 =88\%) and low frequency haplotypes separated by just one mutational step from the dominant (Fig. 4). All individuals from GenBank for the two species (collected also in Deception Island in 2010, five years prior to specimens collected in this study) corresponded to the dominant haplotype. Similarly, A. unilineata comb. nov. presented a star-like haplotype network with a dominant haplotype (Huni_1=62\%) with 7 low frequency haplotypes, the majority of which only had one unique mutational step difference respect to the dominant haplotype (Fig. 4). Haplotype $(H d=0.591)$ and nucleotide diversity $(\pi=0.0019)$ for A. unilineata comb. nov. were higher when compared with that of their congeneric species (Table 1).

The COI genetic distances between the three species ranged from $5.4(\mathrm{~K} 2 \mathrm{p}$ ) to $5.2 \%$ ( $p$ distance) between $\mathrm{pp}=0.97-0.99$ and $\mathrm{bv}=90-99$; green colour indicates $\mathrm{pp}=0.93-0.96$ and $\mathrm{bv}=80-89$; blue colour indicates $\mathrm{pp}=0.90-0.92$ and $\mathrm{bv}=70-79$. No information in the nodes indicates that node was recovered with $\mathrm{pp}<0.90$ and $\mathrm{bv}<70$. The Antarctic Antarctonemertes clade is highlighted in blue and the new individual included in our analyses is in blue bold. (Color figure online)

A. riesgoae and A. valida, to $6.5 \%(\mathrm{~K} 2 \mathrm{p})$ and $6.2 \%$ ( $p$ distance) between $A$. riesgoae and $A$. unilineata comb. nov. (Table 2). The within-species genetic divergence was the lowest for A. riesgoae and A. valida (Table 2). The COI genetic distances between the different genera considered in this study was always greater than $12 \%$ and ranged from $13.8 \%$ (K2p) and $12.6 \%$ ( $p$ distance) between Oerstedia and the non-Antarctic Antarctonemertes, to $20.1 \%$ (K2p) and $17.5 \%$ ( $p$ distance) between Ototyphlonemertes and the non-Antarctic Antarctonemertes (Table 3). The within genera genetic divergence varied dramatically and ranged from $0.37 \%$ (K2p and $p$ distance) in Oerstedia, to $21.58 \%$ (K2p) and $18.55 \%$ ( $p$ distance) in Ototyphlonemertes (Table 3 ).

\section{Discussion}

As noted by Strand and Sundberg (2005), the use of morphological species delimitation in genera such as Tetrastemma is questionable. Here we follow the current trend in nemertean 
Fig. 4 COI haplotype networks for Antarctonemertes riesgoae, Antarctonemertes valida and Antarctonemertes unilineata comb. nov. Colour coding for A. riesgoae and A. valida corresponds to samples collected in our study in 2013 and samples collected in 2010 in the study by Taboada et al. (2013). Missing inferred haplotype for A. valida in black. (Color figure online)

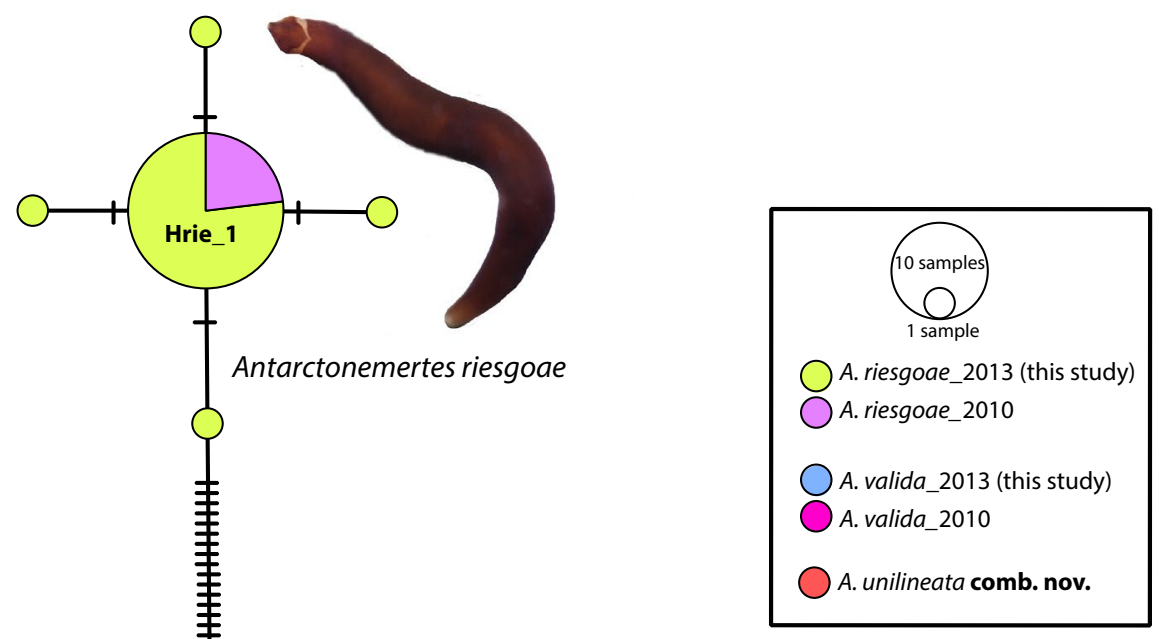

Antarctonemertes unilineata comb. nov.

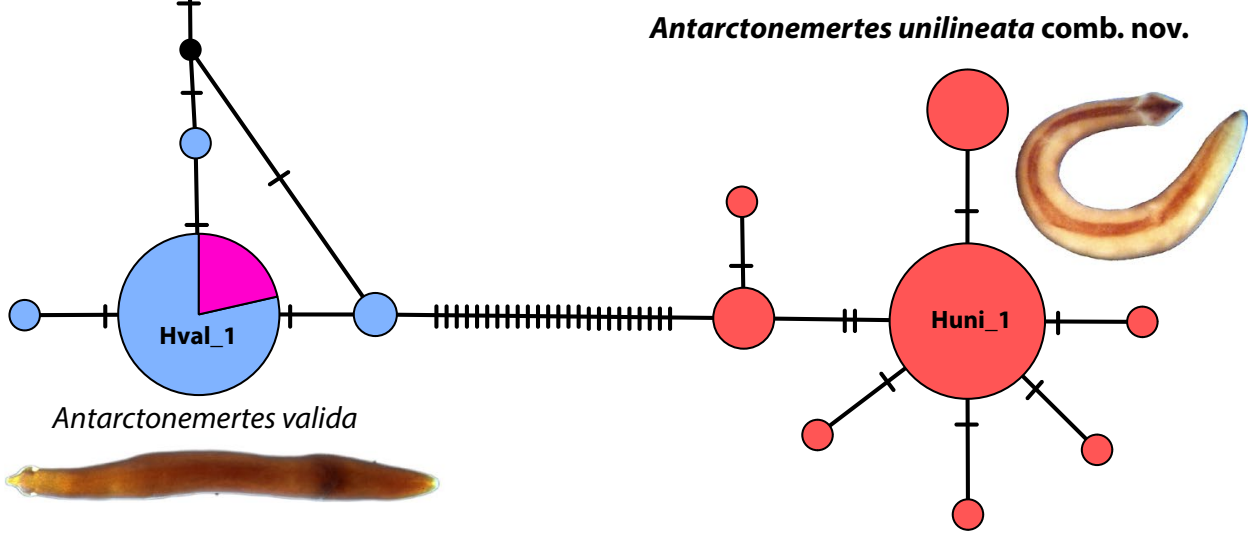

Table 1 Summary of the genetic variability for the COI for the three different Antarctonemertes species considered in the study. $N$ number of individuals, $H$ number of haplotypes, $N p$ number of polymorphic sites, $H d$ haplotype diversity, $\pi$ nucleotide diversity

\begin{tabular}{|c|c|c|c|c|c|}
\hline Species & $N$ & $H$ & $N p$ & $H d$ & $\pi$ \\
\hline A. riesgoae & 30 & 5 & 4 & $0.253 \pm 0.104$ & $0.0005 \pm 0.0002$ \\
\hline $\begin{array}{l}\text { A. unilineata } \\
\text { comb. nov. }\end{array}$ & 42 & 8 & 8 & $0.591 \pm 0.079$ & $0.0019 \pm 0.0004$ \\
\hline A. valida & 32 & 4 & 3 & $0.236 \pm 0.009$ & $0.0005 \pm 0.0002$ \\
\hline
\end{tabular}

taxonomy of combining external morphological characters with molecular data to place the species within its phylogenetic context (e.g. Sundberg and Strand 2010; Strand et al. 2013; Taboada et al. 2013; Herrera-Bachiller et al. 2015).

Table 2 Percentage of $\mathrm{COI}$ genetic distances and standard error using $\mathrm{K} 2 \mathrm{p}$ and $p$ distance methods (left and right of each pairwise comparison, respectively) for the three Antarctic Antarctonemertes. Values
Traditionally, an hoplonemertean with four eyes, without other distinguished characteristic, was included in the genus Tetrastemma (see Strand and Sundberg 2005). Thus, it is unsurprising that the two Antarctic Antarctonemertes species described by Bürger (1898; 1904), A. valida and A. belgica, were originally assigned to Tetrastemma. This poorly defined genus also included the Antarctic species Tetrastemma unilineatum described by Joubin (1910).

Here we report the taxonomical status of Tetratemma unilineatum as belonging to the genus Antarctonemertes establishing a new combination for the species, thus increasing the number of Antarctic Antarctonemertes to four after $A$. belgica, A. riesgoae and A. valida (Bürger 1904; Friedrich 1955; Taboada et al. 2013). The general appearance of live

below the diagonal correspond to pairwise comparisons between species, while values in the diagonal correspond to within species distances

\begin{tabular}{lccc}
\hline & A. unilineata comb. nov & A. riesgoae & A. valida \\
\hline A. unilineata comb. nov & $0.19 \pm 0.08 / 0.19 \pm 0.08$ & & \\
A. riesgoae & $6.5 \pm 1.1 / 6.2 \pm 1.0$ & $0.05 \pm 0.02 / 0.05 \pm 0.02$ & $0.05 \pm 0.02 / 0.05 \pm 0.02$ \\
A. valida & $5.6 \pm 1.1 / 5.4 \pm 1.0$ & $5.4 \pm 1.1 / 5.2 \pm 0.9$ & \\
\hline
\end{tabular}




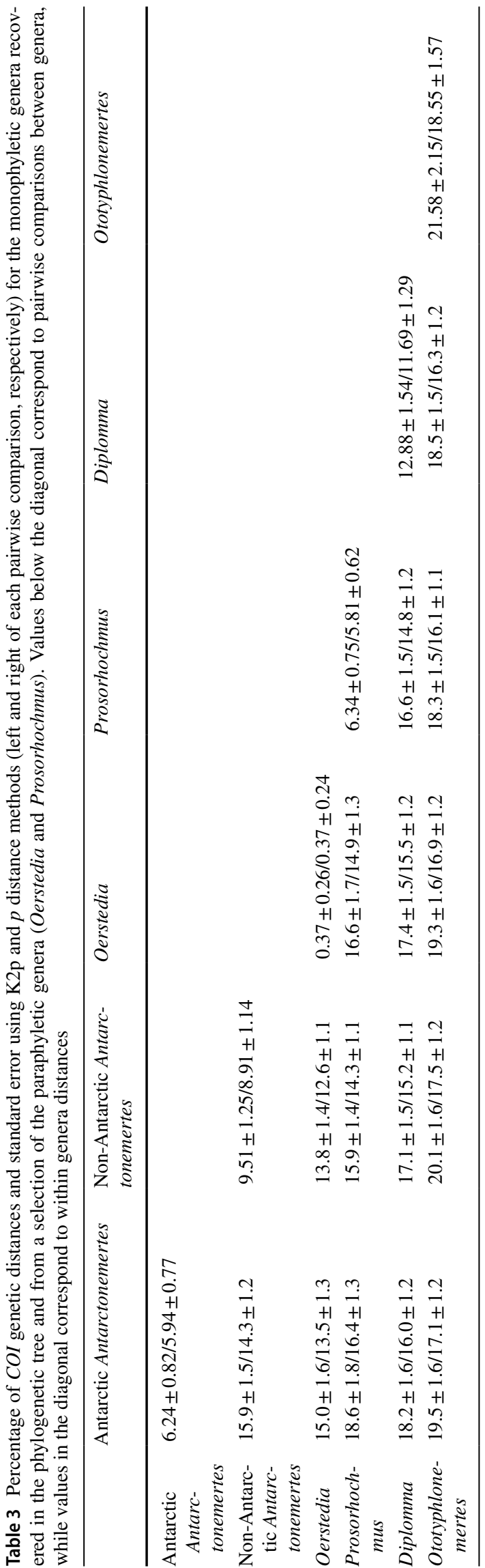

adults of $A$. riesgoae, A. valida and A. unilineata comb. nov. is quite similar, with $A$. unilineata comb. nov. being slightly smaller than $A$. riesgoae and A. valida. Both A. riesgoae and $A$. unilineata comb. nov. have a pair of cephalic furrows ventrally forming a semicircular arch in addition to a white V-shaped cephalic posterior directed band (Taboada et al. 2013). Interestingly, females of A. riesgoae, A. valida and $A$. unilineata comb. nov. build cocoons with two openings where they lay and incubate their eggs, to the authors' knowledge something that was never reported in any studies investigating T. unilineatum (Joubin 1910; Baylis 1915; Wheeler 1940; Coe 1950; Gibson and Tait 1984).

Our phylogenetic results confirm that the Antarctic Antarctonemertes clade is monophyletic and also indicate that the genus Antarctonemertes is paraphyletic (Fig. 3). Paraphyly is also supported by the genetic distances we observed between Antarctic and non-Antarctic Antarctonemertes ( $15.9 \%$ for K2p and $14.3 \%$ for $p$ distance), which were similar to those calculated for the remainder of pairwise comparisons between genera (Table 3). Our results therefore indicate that species in the Antarctic and non-Antarctic Antarctonemertes should not be considered as members of the same genus. Considering that A. valida is the type species of the genus, the generic epithet should only be used for the Antarctic Antarctonemertes and, consequently, the species A. varvarae and A. phyllospadicola should be transferred to another genus, probably the genus Kurilonemertes established as subgenus by Chernyshev (1993) to designate boreal species of the genus Antarctonemertes. However, a comprehensive phylogenetic analysis should be conducted including all Antarctonemertes before taxonomical actions are taken, which is beyond the scope of our study. Furthermore, the pairwise $C O I$ genetic distances between the three Antarctic Antarctonemertes ranged from 5.2 to $6.2 \%$, these values being greater than the 3\% ( $p$ distance) threshold suggested as a barcode gap for nemerteans (Sundberg et al. 2016b).

The haplotype networks recovered for each of the Antarctic Antarctonemertes were similar, all being star-like with a dominant central (probably ancestral) haplotype and low frequency haplotypes deriving from the former (Fig. 4), a pattern indicative of bottleneck events followed by population expansion (Slatkin and Hudson 1991). Similar star-like haplotype networks were recovered for the Antarctic shallowwater common echinoid Sterechinus neumayeri (Meissner, 1900) from both the Antarctic Peninsula and Terra Adélie (East Antarctica) (Díaz et al. 2011). Furthermore, the common heteronemertean Parborlasia corrugatus and the deepwater shrimps Chorismus antarcticus (Pfeffer, 1887) and Nematocarcinus lanceopes Spence Bate, 1888 also displayed similar star-like haplotype networks, although several populations across the Southern Ocean were studied together for these three species (Thornhill et al. 2008; Raupach et al. 2010). However, it is important to note that the echinoid, the 
heternomertean and the two shrimps mentioned above all have planktotrophic larvae and hence large dispersal capabilities, in contrast to what we know for the Antarctonemertes species studied here. Haplotype and nucleotide diversity were slightly higher in A. unilineata comb. nov. when compared to A. riesgoae and A. valida. Given that only one population per species were considered in our study, it would be premature to propose any further conclusions based on these observations, and further studies including samples from other areas are needed. Interestingly, the specimens of $A$. valida and A. riesgoae collected at Deception Island in 2010 by Taboada et al. (2013) shared the dominant haplotype with samples collected in our study in 2013 (Fig. 4). Whether this lack of variability in the haplotypes found in several years is a typical pattern for these species across their range or it is related to the characteristics of Deception Island (a natural harbour with a relatively low connection to the open sea; Lenn et al. 2003), remains unclear. Interestingly, a previous study on the siboglinid annelid Osedax deceptionensis Taboada et al., 2013 at Deception Island found that the haplotype of a single specimen collected in 2010 did not match any of the 11 haplotypes (out of 18 individuals) reported in the same location two years later (Taboada et al. 2015). However, O. deceptionensis has a lecithotrophic larval stage that confers this species remarkable dispersal abilities as opposed to Antarctonemertes species (Taboada et al. 2015).

Antarctonemertes riesgoae, A. valida and A. unilineata comb. nov. are relatively abundant organisms in the upper subtidal zone where adults and their cocoons are easily detectable under rocks and/or attached to algae (Taboada et al. 2013); A. belgica, though, was described by Bürger (1904) in the intertidal of the South Shetland islands and, to our knowledge, never reported again. Extensive surveys along the South Shetland Islands and West Antarctic Peninsula during the past few years have identified abundant populations of $A$. riesgoae and $A$. valida usually occurring in sympatry (authors' unpublished data). However, other authors have reported the occurrence of A. unilineata comb. nov. in the Western Antarctic Peninsula (de la Uz 2005), implying that the four Antarctic Antarctonemertes species at least partially overlap in their distribution. Nevertheless, our observations in the vicinities of Casey station and previous studies indicate that $A$. unilineata comb. nov. is more frequent in the East Antarctic shores and sub-Antarctic Islands (Dawson 1969). Further extensive studies in previously unexplored areas across the Southern Ocean and subAntarctic Islands may challenge this observed trend.

Acknowledgements Thanks are due to F.J. Cristobo, J. Moles, C. Angulo-Preckler, C. Avila, M. Bas, M. Ojeda and the crews of the BAE Gabriel de Castilla and BIO-Hespérides for their support during the sampling at the South Shetland Islands. Special thanks are given to Prof. P.L. Harrison and G. Giribet for the pictures of the living organisms. Thanks are also due to M. Taboada-Riesgo for his support during manuscript writing. We would also like to acknowledge Dr. M. Stand and two anonymous reviewers for their useful comments.

Funding This work was developed within the DISTANTCOM research project (CTM2013-42667/ANT) and the NHM Departmental Internal Funds for A. Riesgo. Collections from Casey station were funded and supported by the Australian Antarctic Division through an Australian Antarctic Science Grant awarded to P.L. Harrison, C.K. King, S.C. George, and A. Lane (Project 4142). C. Leiva was funded by the Departmental Collaboration Grants Program by the Spanish Government.

\section{Compliance with ethical standards}

Conflict of interest No potential conflict of interest was reported by the authors.

Open Access This article is distributed under the terms of the Creative Commons Attribution 4.0 International License (http://creativeco mmons.org/licenses/by/4.0/), which permits unrestricted use, distribution, and reproduction in any medium, provided you give appropriate credit to the original author(s) and the source, provide a link to the Creative Commons license, and indicate if changes were made.

\section{References}

Bandelt HJ, Forster P, Röhl A (1999) Median-joining networks for inferring intraspecific phylogenies. Mol Biol Evol 16:37-48

Baylis HA (1915) Nemertinea. British Antarctic Terra Nova Expedition 1910. Zoology 2:113-134

Bürger O (1893) Südgeorgische und andere exotische Nemertinen. Zoologische Jahrbücher, Abteilungen Systematik, Ökologie und Geographic der Tiere 7:207-240

Bürger O (1904) Nemertinen Resultats du voyage du SY Belgica en 1897-1899, Zoologie, 1-10

Castresana J (2000) Selection of conserved blocks from multiple alignments for their use in phylogenetic analysis. Mol Biol Evol 17:540-552

Chernyshev AV (1993) Novuie svedeniya o sistematike nemertin semeistva Cratenemertidae (Enopla, Monostilifera). Vestn Zool 1:72-75

Chernyshev AV (1999) Nemerteans of the genus Antarctonemertes (Enopla, Monostilifera). Zool Zhurnal 78:939-948

Coe WR (1950) Nemerteans from Antarctica and the Antarctic Ocean. J Wash Acad Sci 40:56-59

Dawson EW (1957) Checklist of marine nemertines from Antarctica. Special Report of the Royal Society of New Zealand Antarctic Research Communication 22:1-10

Dawson EW (1969) Nemertea. In: Distribution of selected groups of marine invertebrates in waters south of $35^{\circ} \mathrm{S}$ latitude. Antarctic Map Folio Series, Folio 11:18-21

Dawson EW (1971) Nemertea. Coll Repr N Z Oceanogr Inst 289:1-9

de la Uz S (2005) Fauna bentónica de nemertinos (Hoplonemertea) antárticos - BENTART 2003. Seminario de Investigación. Universidad de Oviedo. http://www.bentart.es/articulos/De_la_Uz Nemertinos_DEA_Univ_Oviedo.pdf. Accessed 31 January 2018

Díaz A, Féral JP, David B, Saucède T, Poulin E (2011) Evolutionary pathways among shallow and deep-sea echinoids of the genus Sterechinus in the Southern Ocean. Deep-Sea Res Pt II 58:205-211

Envall M, Sundberg P (1993) Intraspecific variation in nemerteans (Nemertea): synonymization of genera Paroerstedia and Oerstediella with Oerstedia. J Zool 230:293-318 
Friedrich H (1955) Beiträge zu einer Synopsis der Gattungen der Nemertini monostilifera nebst Bestimmungsschlüssel. Z Wiss Zool Abt A 158:133-192

Gibson R (1983) Antarctic nemerteans: the anatomy, distribution and biology of Parborlasia corrugatus (McIntosh, 1876) (Heteronemertea: Lineidae). Antar Res S 39:289-316

Gibson R (1985) The need for a standard approach to taxonomic descriptions of nemerteans. Am Zool 25:5-14

Gibson R (1995) Nemertean genera and species of the world: an annotated checklist of original names and description citations, synonyms, current taxonomic status, habitats and recorded zoogeographic distribution. J Nat Hist 29:271-561

Gibson R, Tait NN (1984) A redescription of Tetrastemma unilineatum Joubin 1910, and Antarctic hoplonemertean (Nermertini). Zool Anz 212:139-150

Herrera-Bachiller A, Kvist S, Giribet G, Junoy J (2015) Redescription of Micrura dellechiajei (Hubrecht, 1879) (Nemertea, Pilidiophora, Lineidae), a rare Mediterranean species. J Mar Biol Assoc UK 95:1091-1100

Johnston G (1837) Miscellanea Zoologica. II. A description of some planarian worms. Mag Zool Bot 1:529-538

Joubin L (1910) Nemertinea. National Antarctic Expedition 19011904. 5:1-15

Joubin L (1914) Némertiens. Deuxième Expédition Antarctique Française 1908-1910(5):1-33

Kajihara H, Chernyshev A, Sun S-C, Sundberg P, Crandall FB (2008) Checklist of nemertean genera and species published between 1995 and 2007. Species Divers 13:245-274

Katoh K, Kuma K, Toh H, Miyata T (2002) MAFFT version 5: improvement in accuracy of multiple sequence alignment. Nucleic Acids Res 33:511-518

Kearse M, Moir R, Wilson A, Stones-Havas S, Cheung M, Sturrock S, Buxton S, Cooper A, Markowitz S, Duran C, Thierer T, Ashton B, Mentjies P, Drummond A (2012) Geneious Basic: an integrated and extendable desktop software platform for the organization and analysis of sequence data. Bioinformatics 28:1647-1649

Lenn YD, Chereskin TK, Glatts RC (2003) Seasonal to tidal variability in currents, stratification and acoustic backscatter in an Antarctic ecosystem at Deception Island. Deep-Sea Res Pt II 50:1665-1683

Librado P, Rozas J (2009) DnaSP v5: a software for comprehensive analysis of DNA polymorphism data. Bioinformatics 25:1451-1452

Mahon AR, Thornhill DJ, Norenburg JL, Halanych KM (2010) DNA uncovers Antarctic nemertean biodiversity and exposes a decadesold cold case of asymmetric inventory. Polar Biol 33:193-202

McIntosh WC (1876) Descriptions of some new species of Annelida from Kerguelen's Island. Ann Mag Nat Hist 4(17):318-323

Posada D (2008) jModelTest: phylogenetic model averaging. Mol Biol Evol 25:1253-1256

Rambaut A (2006) FigTree v1.3.1. Computer software and manual http://tree.bio.ed.ac.uk/software/figtree

Rambaut A, Suchard MA, Xie D, Drummond AJ (2014) Tracer v1.6. [Computer software and manual]. http://beast.bio.ed.ac.uk/Tracer

Raupach MJ, Thatje S, Dambach J, Rehm P, Misof B, Leese F (2010) Genetic homogeneity and circum-Antarctic distribution of two benthic shrimp species of the Southern Ocean, Chorismus antarcticus and Nematocarcinus lanceopes. Mar Biol 157:1783-1797

Roe P, Norenburg JL, Maslakova S (2007) Nemertea. In: Carlton JT (ed) The Light and Smith Manual: Intertidal Invertebrates from Central California to Oregon, 4th edn. University of California Press, Berkeley and Los Angeles, pp 221-233
Ronquist F, Huelsenbeck JP (2003) MrBayes 3: bayesian phylogenetic inference under mixed models. Bioinformatics 19:1572-1574

Slatkin M, Hudson RR (1991) Pairwise comparisons of mitochondrial DNA sequences in stable and exponentially growing populations. Genetics 129:555-562

Stamatakis A (2006) RAxML-VI-HPC: maximum likelihood-based phylogenetic analyses with thousands of taxa and mixed models. Bioinformatics 22:2688-2690

Stamatakis A, Hoover P, Rougemont J (2008) A fast bootstrapping algorithm for the RaxML web-servers. Syst Biol 57:758-771

Strand M, Sundberg P (2005) Delimiting species in the hoplonemertean genus Tetrastemma (phylum Nemertea): morphology is not concordant with phylogeny as evidenced from mtDNA sequences. Biol J Linn Soc 86:201-212

Strand M, Herrera-Bachiller A, Nygren A, Kånneby T (2013) A new nemertean species: what are the useful characters for ribbon worm descriptions? J Mar Biol Assoc UK 94:317-330

Stricker SA (1985) A new species of Tetrastemma (Nemertea, Monostilifera) from San Juan Island, Washington, USA. Can J Zool 63:682-690

Sundberg P, Strand M (2010) Nemertean taxonomy-time to change lane? J Zool Syst Evol Res 48:283-284

Sundberg P, Chernyshev AV, Kajihara H, Kånneby T, Strand M (2009) Character-matrix based descriptions of two new nemertean (Nemertea) species. Zool J Linn Soc-Lond 157:264-294

Sundberg P, Andrade S, Bartolomaeus T, Beckers P, Döhren J, Krämer D, Gibson R, Giribet G, Herrera-Bachiller A, Junoy J, Kajihara H, Kvist S, Kannaby T, Sun S-C, Thiel M, Turbeville JM, Strand M (2016a) The future of nemertean taxonomy (phylum Nemertea) a proposal. Zool Scr 45:579-582

Sundberg P, Kvist S, Strand M (2016b) Evaluating the utility of singlelocus DNA barcoding for the identification of ribbon worms (Phylum Nemertea). PLoS ONE 11:e0155541

Taboada S, Junoy J, Andrade SC, Giribet G, Cristobo J, Avila C (2013) On the identity of two Antarctic brooding nemerteans: redescription of Antarctonemertes valida (Bürger, 1893) and description of a new species in the genus Antarctonemertes Friedrich, 1955 (Nemertea, Hoplonemertea). Polar Biol 36:1415-1430

Taboada S, Riesgo A, Bas M, Arnedo MA, Cristobo J, Rouse GW, Avila C (2015) Bone-eating worms spread: insights into shallowwater Osedax (Annelida, Siboglinidae) from Antarctic, Subantarctic, and Mediterranean waters. PLoS ONE 10:e0140341

Tamura K, Peterson D, Peterson N, Stecher G, Nei M, Kumar S (2011) MEGA5: molecular evolutionary genetics analysis using maximum likelihood, evolutionary distance, and maximum parsimony methods. Mol Biol Evol 28:2731-2739

Thollesson M, Norenburg JL (2003) Ribbon worm relationships: a phylogeny of the phylum Nemertea. Proc Roy Soc Lond B Bio 270:407-415

Thornhill DJ, Mahon AR, Norenburg JL, Halanych KM (2008) Openocean barriers to dispersal: a test case with the Antarctic Polar Front and the ribbon worm Parborlasia corrugatus (Nemertea: Lineidae). Mol Ecol 17:5104-5117

Verrill AE (1892) The marine nemerteans of New England and adjacent waters. Trans Conn Acad Arts Sci 8:382-456

Wheeler JFG (1940) Nemerteans of Kerguelen and the Southern Ocean, Report, B.A.N.Z. Antarctic Research Expedition 19291931. Series B 4:233-256 